\title{
The Triple Bottom Line Effect on Emerging Market Companies: A Test of Corporate Social Responsibility and Firm Value Relationship
}

\author{
M. Yasser Arafat ${ }^{1}$, Ari Warokka ${ }^{2}$, Haim Hilman Abdullah ${ }^{2}$ and Rosa Rachmat Septian ${ }^{1}$ \\ ${ }^{1}$ Faculty of Economics - UNJ, Indonesia \\ ${ }^{2}$ College of Business - UUM, Sintok, Malaysia
}

\begin{abstract}
Over the last twenty years, after corporations have historically focused their reporting systems on the provision of financial information needed by managers and shareholders to assess risks and calculate returns, the global awareness of the need to assess the full spectrum of corporate value has grown dramatically. The triple bottom line or total returns on capital-economic, social, or environmental-are now tracked with increasing regularity. Prior research has revealed that a significant pressure of economic changes, an increase in interest in corporate social responsibility (CSR) in recent years, and an acknowledgement of it as an important research topic has brought a bigger and wider effort to build a comprehensive framework. Little empirical research on the effect of corporate social responsibility together with profitability on firm value is done in Southeast Asian countries. This study extends the literature that has been done mostly in western societies by proposing a further linkage between social responsibility, profitability, and firm value, which is rarely investigated in non-western societies. The study analyzed 35 Indonesian manufacturing firms that are listed in Indonesian Stock Exchange (IDX) and report their CSR as the supplement in the annual report. Statistic methods used for testing the hypothesis are T-test and multivariate regression model. The empirical results reveal that CSR has significantly influenced the firm value of Indonesian manufacturing companies. However, one striking finding in this study is the insignificant influence of two measures of profitability, i.e. ROA and ROE, over firm value of those companies have good CSR. These results explicitly show how firms in emerging countries are going to be more concerned with social sustainability and long-run profitability.
\end{abstract}

Keyword: Corporate Social Responsibility, Profitability, Firm Performance, Sustainability.

\section{Introduction}

The dynamic economic changes and pressure on firms to engage in corporate social responsibility (CSR) activities and establish themselves as highly socially responsible companies have increased during the last three decades. It means that in the dynamic perspective of global competitive market, companies must endeavor to reveal a picture of themselves as socially responsible- oriented companies. It is because active involvement in socially beneficial programs will provide extra advantages to the company. The primary idea is that corporate social responsibility (CSR) could be considered to increase long-term profitability and sustainability of the company as well as enhance the reputation of the organization.

Generally, CSR is also understood to be the way a company attains a balance or

Copyright (C) 2012 M. Yasser Arafat, Ari Warokka, Haim Hilman Abdullah and Rosa Rachmat Septian. This is an open access article distributed under the Creative Commons Attribution License unported 3.0, which permits unrestricted use, distribution, and reproduction in any medium, provided that original work is properly cited. Contact author: M. Yasser Arafat E-mail: aa71_2001@yahoo.com 
integration of economic, environmental, and social imperatives, while at the same time, addressing shareholder and stakeholder expectations, with the understanding that businesses play a key role on job and wealth creation in society. CSR has become a prominent topic, whether in the business or in academic press. Nevertheless, opinions differ as to whether a firm's CSR activity provides any economic benefits. More generally, a distinction has been drawn between CSR seen as philanthropy contrary to CSR as a core business activity (Jones, Comfort, and Hiller, 2007).

After many decade corporations have historically focused their reporting systems on the provision of financial information needed by managers and shareholders to assess risks and calculate returns, over the last twenty years, however, global awareness of the need to assess the full spectrum of corporate value has grown dramatically. It focuses right now on the triple bottom line or 'total returns' on capital-economic, social, or environmental-, which are now tracked with increasing regularity.

Research has indicated that increased attention to the 'triple bottom line' can have direct and indirect benefits on productivity, efficiency, security risks and corporate image. By assessing and improving the triple bottom line, companies benefit from increased operational efficiency, cleaner production, improved relations with stakeholders and increased access to new business opportunities.

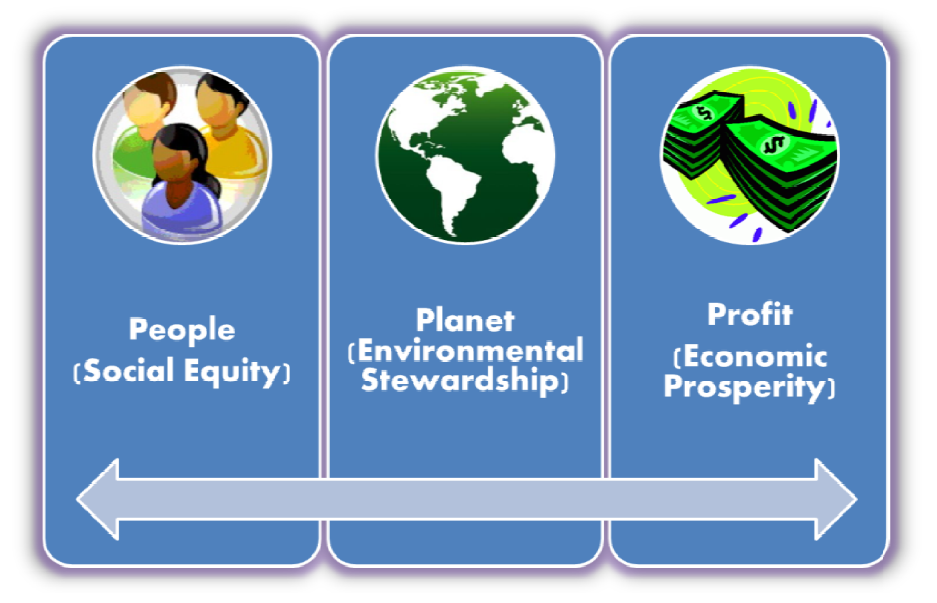

Fig 1: Triple Bottom Line

Numerous scholars view that, corporate social performance is a kind of virtuous circle, there is a simultaneous relationship, and corporate social performance is both a predictor and consequence of a company financial performance. Therefore, numerous studies have been conducted to measure the statistical association between perceived corporate social responsibility (CSR) and corporate financial performance (CFP), to aid the understanding of the relationship between CSR and CFP. Some scholars have identified some groups of studies in CSR area, such as Pava and Krausz (1996) identified and reviewed 21 empirical studies in this area, while Margolis and Walsh (2003) reported that 122 published studies empirically examined the relationship between CSR and CFP during the period 1971 - 2001. Furthermore, Orlitzky, Schmidt, and Rynes (2003) conducted a meta-analysis of 52 studies, which revealed that most results of prior studies found that CSR had a positive impact on financial performance. 
Even though the number of CSR studies is high and has been extensively explored in developed markets, there is to date, so few empirical studies of the impact of CSR and financial performance on firm value in an Indonesian context. The trend in developed markets such as North America and Europe show there have been widespread empirical tests of the relationship between CSR, profitability, and firm value. There are, however, no published studies, in the Indonesian context, that have explored the impact of CSR and profitability on the financial performance of local companies engaging in CSR. The lack of information from academic literature concerning whether CSR has any substantiated impact on profitability and firm value in local companies may be one of the possible reasons why company's disclose little of their CSR activities. Gelb and Strawser (2001) state that firms have incentives to engage in stakeholder management by undertaking socially responsible activities and that providing extensive and informative disclosures is one such practice. Therefore, this study seeks to fill the gaps in the empirical study of the impact of CSR and profitability on firm value.

\section{Research Question}

Prior empirical findings reveal that firms having low in social responsibility also experience lower return on assets (ROA) and stock-market returns than do firms high in social responsibility. Cochran and Wood (1984) reexamined the relationships between corporate social responsibility and financial performance, and they found that exclusion of asset turnover and asset age led to spurious positive correlations between CSR and financial performance, and with this variable included; there is still weak evidence of positive correlation between the CSR and financial value. Mostly, there are two types of empirical studies of the relationship between the CSR and financial value (Clinebell and Clinebell, 1994; Hannon and Milkovich, 1996; Posnikoff, 1997; Teoh, Welch, and Wazzan, 1999; Worrell, Davidson, and Sharma, 1991;
Wright and Ferris, 1997). Some studies use the event study methodology to assess the short-run financial impact (abnormal returns) when firms engage in socially responsible or irresponsible acts, and the results of these studies have been mixed. Teoh et al. (1999) found no relationship between CSR and financial performance. Wright and Ferris (1997) found a negative relationship, and Posnikoff (1997) reported a positive relationship; and McWilliams and Siegel (1997) studies are inconsistent on the relationship between the CSR and short runs financial returns.

In the context of emerging market like Indonesia, prior CSR studies merely explored the content of CSR activities in annual reports and the motivation of why managers engaged in it. Even though there are some pressure from stakeholders towards companies that more actively engage in CSR activities, the number of companies involved in CSR disclosures is still relatively low (Nurlela and Islahudin, 2008). Prior studies also found that CSR activities are the only supplement reports and tend to be voluntarily effort (Rakhiemah and Agustia, 2009). There is a gap in the studies concerning any impact of companies disclosing CSR activities towards their firm value. This issue has the strategic implications, because managers need to know whether their firms will have an economic advantage and receive a positive response from their long-term investors. Therefore, it is worth examining if CSR disclosure is related to a firm's value. Thus, this study addresses the gap in the existing literature of the inter-relationship between CSR, profitability, and firm performance, which this study will stimulate more studies in this direction. At the same time, this study also helps create comparative findings in emerging capital markets. There are two major objectives of this study - first, to explore whether there is evidence of any impact between CSR, profitability, and firm value for companies listed in Indonesia Stock Exchange (IDX); and second, to explore whether any impact exists between dimensions of CSR, profitability, and firm 
performance. This study will try to contribute in this area and may facilitate more intensively researches on CSR, profitability, and firm value links outside of the U.S and European markets in the future, especially in emerging capital markets.

\section{Literature Review}

Corporate social responsibility (CSR) is defined about how businesses align their values and behavior with the expectations and needs of stakeholders-not just customers and investors, but also employees, suppliers, communities, regulators, special-interest groups, and society as a whole (Ahmed and Uchida, 2009). CSR describes a company's commitment to be accountable for its stakeholders. CSR is necessary a growing term that does not have a standard definition or fully recognized set of specific criteria. Social and environmental disclosure can typically be thought of as providing information relating to company's activities, aspirations and public image with regard to environmental, community, employee and consumer issues (Gray, Javad, Power, and Sinclair, 2001). Haron, Yahya, Chambers, Manasseh, and Ismail (2004) indicate that social disclosure can provide either positive information, which presents the company as operating in harmony with the environment, such as stating that the company is conducting training programmes for employees or that waste-management policies are being undertaken, or negative information, which presents the company as operating to the detriment of environment, such as the inability to control or reduce pollution or failure to solve a social problem.

The empirical study of CSR and firm value started over three decades ago in developed countries. There are basically two mainstreams of empirical study of the relationship between CSR and firm value. First, it uses the event study methodology to gauge the short-run financial impact (abnormal returns) when firms engage in socially responsible or irresponsible acts (e.g Hannon and Milkovich, 1996; McWilliams and Siegel, 2000; Posnikoff, 1997; Wright and Ferris, 1997). The results of these studies have been mixed. For example, Wright and Ferris (1997) found a negative relationship; Posnikoff (1997) reported a positive relationship; and McWilliams and Siegel found no relationship between CSR and financial performance. Other studies are similarly inconsistent concerning the relationship between CSR and short-run financial returns (McWilliams and Siegel, 2001).

The second mainstream of studies examines the nature of the relationship between some measures of corporate social performance, corporate social performance (a measure of CSR), and measures of the long-term firm performance, using accounting or financial measures of profitability (e.g Mahoney and Roberts, 2007; McWilliams and Seigel, 2000; Simpson and Kohrer, 2002). The results from these studies have also been mixed. Aupperle, Carrol, and Hatfield (1985) found no relationship between CSR and profitability. McGuire, Sundgren, and Schneeweis (1988) found that prior performance was more closely related to CSR than subsequent performance, and Simpson and Kohrer (2002), Waddock, and Graves (1997) found a significant positive relationship.

According to Griffin and Mahon (1997), prior studies that explored the corporate social and financial performance link were often interested in a single dimension of social performance, such as environmental pollution. Further, Griffin and Mahon (1997) summarized the empirical findings of the numerous articles they reviewed and concluded that no definitive consensus exists on the empirical corporate social and financial performance link, and that while a substantial number of studies found a negative relationship, some of the studies have been inconclusive because they found both positive and negative relationships. However, most of the investigations found a positive link. 
In the context of single industry, Simpson and Kohers (2002) studied an extension of earlier research on the relationship between corporate social and financial performance, by analyzing companies from the banking industry and using the Community Reinvestment Act (CRA) ratings as a social performance measure. Their results solidly supported the hypothesis that the link between social and financial performance is positive. Furthermore, Moore and Robson (2002) also analyzed a single industry with a study of the social and financial performance of eight firms in the UK supermarket industry. By using the derivation of a 16measure social performance index and a 4measure financial performance index, there was only one statistically significant result. Meanwhile, in the context of large sample of four-year panel data, Mahoney and Roberts (2007) found no significant relationship between a composite measure of companies' social and financial performance. However, they found significant relationships between individual measures of companies' social performance regarding environmental and international activities and financial performance.

The state of CSR in Indonesia is still in an early stage, through development has indicated encouraging signs. Four or five years ago, CSR was still considered "alien" and awareness of the concept was very low. Indonesian companies, particularly those operating in the global market have become increasingly aware that they are required to balance the economic, social, and environmental components of their business, while building the shareholder value. Related to this Indonesia situation, Subroto (2002) initiated the study of relationship between corporate social responsibility and financial performance towards ethical business practices by using an explanatory survey and multivariate correlations, cross-sectioned data and critical part analyses, to analyze a correlation study. This study tested three hypotheses with results for the first hypothesis. All interests of stakeholders had a significant correlation. Results of the second hypothesis were still positive. Lastly, the third hypothesis indicated that the correlation between social responsibility and financial performance was quite low.

\section{The Relationship of Corporate Social Responsibility Disclosure, Profitability, and Firm Value}

Many scholars often argue that CSR can improve the competitiveness of a company in the long-term, implying a positive relationship between the CSR involvement of a company and its financial success (Weber, 2008). There is also a strong argument that companies that fail to act in a socially responsible manner will experience significant declines in financial performance (Thorne, Ferrel, and Ferrel, 1993). Studying the impact of 131 public announcements of corporate illegalities on the shareholder returns of 96 companies, Davidson and Worrell (1988) support this hypothesis. They found a strong negative correlation between corporate social irresponsibility and stock market performance. Frooman (1997) who analyzed the stock market's reaction to incidences of socially irresponsible or illicit behavior also found the similar finding. He found the effects to be negative, statistically significant, and substantial in size.

Responding to those empirical findings, Brown (1998) argues that companies perceived to be socially irresponsible could be more susceptible to adverse government action (fines and lawsuits) or too drastic reductions in sales due to disclosure of corporate wrongdoing. In other words, companies with strong reputations in relation to CSR are perceived as fewer risky investments because they are less likely to fall foul of regulations or the marketplace. To support this argument, Mallin, Saadouni, and Briston (1995) and Boutin-Dufrnse and Savaria (2004) found a negative relationship between a firm's level of CSR and their level of specific risk. 
Related to the dynamic business environment, Lorca and Garcia-Diez (2004) argue that the business climate has changed remarkably over the past number of years, such that, today success is no longer dependent on customer satisfaction but on the satisfaction of all the stakeholders of the company. It is argued that failure to take the interests of all stakeholders into account results in shareholders unwilling to invest in the firm, customers refusing to buy the firm's products, employees withdrawing their loyalty, suppliers who are unwilling to provide their knowledge, abilities and resources and lastly, communities not tolerating of the company (Lorca and GarciaDiez, 2004). Thus, the long-term survival and success of a firm are determined by its ability to establish and maintain relationships with its entire network of stakeholders (Post, Preston, and Sachs, 2002). This argument is supported by a survey of global companies by Ernst \& Young (2002) that found most companies now explicitly recognize that the value of their organization is dependent on the quality of relationships with key stakeholder groups. Indeed, the motivation to develop a CSR strategy for most companies (94\%) came from awareness that such a strategy can deliver real benefits. It seems that executives are fully aware of this.

Other arguments said that many companies have claimed to increase productivity, decrease costs and increase profitability through aggressive waste reduction (socially environmental activities) and process improvement programs (Brown, 1998; Roberts and Dowling, 2002; Friedman and Miles, 2001). According to Hughes, Anderson, and Golden (2001), environmental performance, which is one of the corporate social responsibility components, can affect financial performance in a number of ways. There are the opportunities to drive down operating costs, such as exploiting ecological efficiencies, reducing waste, conserving energy, reusing material, and recycling companies that can reduce costs.

\section{Hypotheses Development}

Even though prior studies reveal that there are mixed findings, this study adopts the perspective that CSR activities are associated positively with firm value. Hence, CSR helps certain advantages, such as build name recognition, customer loyalty (Rosen, Sandler, and Shani, 1991), and market position (Fombrun and Shanley, 1990), that bring towards better firm value. The perspective of this study is consistent with recent research documenting a positive relationship between $\operatorname{CSR}$ and firm value (Orlitzky et al., 2003; Roman, Hayibor, and Agle, 1999; Ruf, Muralidhar, Brown, Janney, Paul, 2001; Simpson and Kohers, 2002; Tsoutsoura, 2004; Waddock and Graves, 1997). At the same time, this study will also try to find whether CSR activities together with profitability measures simultaneously affect the firm value, which this hypothesis is previously not tested in prior studies. Therefore, based on those arguments, the first hypothesis is:

\section{$H_{1}$ : There is an association between corporate social responsibility and firm value.}

\section{$\mathrm{H}_{2}$ : Corporate social responsibility and profitability simultaneously are associated with firm value.}




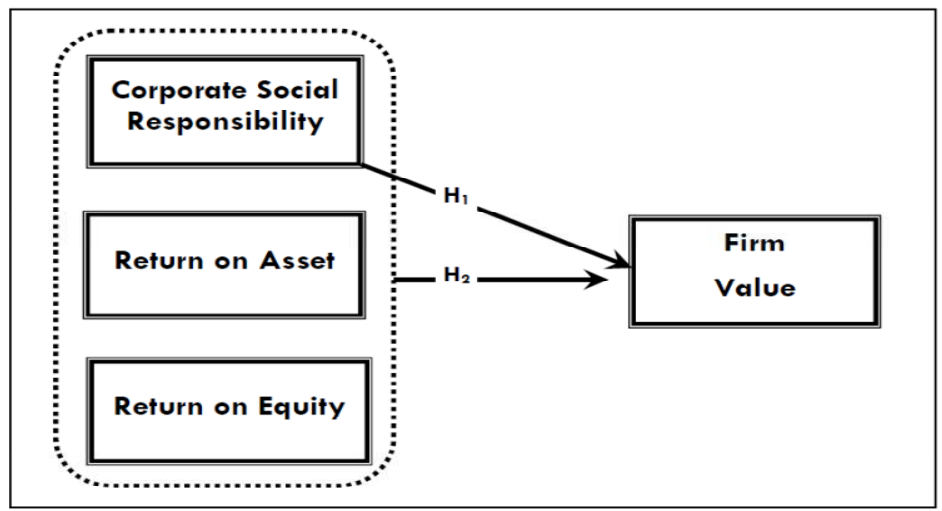

Fig. 2: Research Model of the Relationship of Corporate Social Responsibility, Profitability and Firm Value

\section{Research Methodology}

In this study, the sample consists of the 35 manufacturing companies, which are taken out of 142 manufacturing companies listed on the main board of Indonesia Stock Exchange (IDX) during the period 2008 to 2009. The selection is based on their full report on corporate social responsibility to IDX. This selection criterion is consistent with previous studies on CSR reporting (e.g. Guthrie and Parker, 1990; Hackston and Milne, 1990; Thompson and Zakaria, 2004). The time span is selected for two reasons: First, this period is the relatively established period of the Introduction of Indonesian Limited Liability Companies Law No. 40/2007 making CSR mandatory for companies operating in any business field related to natural resources, with sanctions to be imposed on non-compliant firms. Second, CSR disclosure is in its infancy period in the emerging capital markets (Thompson and Zakaria, 2004; Tsang, 1998). Data is collected from the companies' annual reports, downloaded through the Indonesia Stock Exchange website and the Central Bank of Indonesia. Companies' annual reports constitute the main data for this study and were chosen because the annual report is the primary source of corporate environmental reporting, and, in Indonesia, annual reports of listed companies are the most accessible source of information, either in hard copies or electronic formats (Christopher, Hutomo, Monroe, 1997; Wiseman, 1982).

To measure CSR disclosure, in this study, we adopted a similar disclosure-scoring methodology based on content analysis that incorporates disclosures of four keys CSR indicators; (1) employee relation; (2) environment; (3) community involvement; and (4) product. Each indicator has sub-item disclosures that are adjusted based on whether the items are disclosed. Furthermore, Al-Tuwaijri, Christensen and Hughes (2004) propose that the process may be achieved using quantitative disclosure measures with denoted weights for different disclosure items based on the perceived importance of each item to various user categories, which also marks the greatest weight $(+3)$ to quantitative disclosures related to the four CSR indicators as described above. Marking the next highest weight $(+2)$ to non-quantitative but specific information related to these indicators. Lastly, common qualitative disclosures receive the lowest weight $(+1)$. Firms that do not disclose any information for the given indicators receive a zero score. This study adopts the above discussed procedures in measuring CSR disclosure. Therefore, the formula to calculate corporate social responsibility disclosure is as follows:

$\operatorname{CSRDI}_{s}=\frac{\sum X_{i s}}{N_{s}}$ 
Where

CSRDI $I_{s}$ : Corporate Social Responsibility Disclosure Index of sampling companies

$\mathrm{X}_{\mathrm{is}}$ : Number of CSRDIs item for company $\mathrm{j}, \mathrm{nj}=18$

$\mathrm{N}_{\mathrm{s}}$ : Dummy variable, if CSRDI item is disclosed $=1$, otherwise 0 .

To measure profitability, in this study, we used Return on Asset (ROA) and Return on Equity (ROE). It is based on the fact that most previous studies used accounting data to measure financial performance. For example, Waddock and Graves (1997) used three accounting variables. Those variables were return on assets (ROA), return on equity (ROE), and return on sales (ROS). Simpson and Kohres (2002) used return on assets (ROA) and loan losses, whereas Berman, Wicks, Kotha, and Jones (1999) only used return on assets (ROA). Prior studies by Cochran and Wood ((1984) also used accounting data to measure profitability. Based on those empirical findings, we used ROA and ROE as profitability variables. The reason for using ROA and ROE as the proxy of profitability is because those measures are less likely to be manipulated and is the most widely used measurement of a firm's profitability (Yoshikawa and Phan, 2003). Meanwhile to measure firm value, we use PER as a dependent variable is because investors primarily care about stock returns (Yoshikawa and Phan, 2003) and using market value rather than accounting-based measures of financial performance has become widespread in the empirical analysis. To test the hypotheses, we employed multivariate regression where firm value was the dependent variable and CSRDI, ROA, and ROE were the independent variables.

\section{Findings and Discussion}

\section{Descriptive Statistics and Classical Assumptions Test}

In this section, descriptive statistics are used to test the bivariate relations by comparing the mean (average) for each variable. The result of descriptive statistics is reported in Table 1. The lowest score of CSR is from an Indonesia-based motor vehicle manufacturing firm; meanwhile, the highest score and value of CSR and PER is from an Indonesia-based bottling water company, which is known as the pioneer in CSR activities in Indonesia. The minimum value of $\mathrm{ROA}$ is from an Indonesia-based polyester manufacturer; meanwhile, the maximum value of ROA and ROE is from an Indonesiabased consumer goods company, which the company's principal activities are the production, marketing and distribution of consumer goods, including soaps, detergents, margarine, dairy-based products, ice cream, cosmetic products, tea-based beverages and fruit juice. The minimum value of ROE is from an Indonesia-based mining and general business company, which its main activities are in mining, construction/infrastructure, forestry, agro industry, oil and gas and general industries. The minimum value of PER is from an Indonesia-based glass manufacturer, which the company is engaged in the manufacturing, exportation and importation of automotive glass, and related activities.

Table 1: Descriptive Statistics

\begin{tabular}{|l|c|c|c|c|c|}
\hline & $\mathrm{N}$ & Minimum & Maximum & Mean & Std. Deviation \\
\hline CSRDI & 43 & 20.25 & 97.47 & 35.56 & 15.32 \\
\hline ROA & 43 & 2.06 & 57.00 & 15.38 & 11.85 \\
\hline ROE & 43 & 4.41 & 82.21 & 23.06 & 15.28 \\
\hline PER & 43 & 2.31 & 33.59 & 11.44 & 7.35 \\
\hline Valid N (listwise) & 43 & & & & \\
\hline
\end{tabular}


9 Journal of Southeast Asian Research

Before doing the regression test, there are three classical assumption tests need to be done, i.e. normality test, multicollinearity test, and heteroscedastic test. To test data normality, we used nonparametric test 1- sample K-S, as can be seen in Table 2. If Kolmogorov-Smirnov coefficient is more than 0.05 , it can be said that the data is normal distributed.

Table 2: One-Sample Kolmogorov-Smirnov Test

\begin{tabular}{|l|l|c|c|c|c|}
\hline \multicolumn{2}{|c|}{} & CSRDI & ROA & ROE & PER \\
\hline $\mathrm{N}$ & 43 & 43 & 43 & 43 \\
\hline \multirow{2}{*}{ Normal Parameters ${ }^{\mathrm{a}}$} & Mean & 35.5607 & 15.3819 & 23.0698 & 11.4442 \\
\cline { 2 - 6 } & Std. Deviation & $1.5329 \mathrm{E} 1$ & $1.18596 \mathrm{E} 1$ & $1.52848 \mathrm{E} 1$ & 7.35843 \\
\hline \multirow{2}{*}{$\begin{array}{l}\text { Most Extreme } \\
\text { Differences }\end{array}$} & Absolute & 0.190 & 0.200 & 0.180 & 0.134 \\
\cline { 2 - 6 } & Positive & 0.190 & 0.200 & 0.180 & 0.134 \\
\cline { 2 - 6 } & Negative & -0.159 & -0.131 & -0.111 & -0.110 \\
\hline \multicolumn{2}{|l|}{ Kolmogorov-Smirnov Z } & 1.249 & 1.314 & 1.177 & 0.876 \\
\hline \multicolumn{2}{|l|}{ Asymp. Sig. (2-tailed) } & 0.088 & 0.063 & 0.125 & 0.426 \\
\hline \multicolumn{2}{|l|}{ a. Test distribution is Normal. } & & \multicolumn{3}{|l}{} \\
\hline
\end{tabular}

Based on information in Table 2, all independent and dependent variables are normal distributed, because the $\mathrm{p}$ values of three independent variables' KS coefficient and the dependent variable's KS coefficient are more than 0.005 . The second classical assumption test is the multicollinearity test. There are two assumptions that must be met, first, Variance Inflation Factor (VIF) value must be lower than 10, and second. The tolerance value is higher than 0.10. Based on information in Table 3, there is not any multicollinearity among independent variables. All variables' values of VIF are lower than 10 , i.e. $1.192,3.784,1.703$, respectively for CSR, ROA, and ROE.

Table 3: Multicollinearity Test

\begin{tabular}{|c|c|c|c|}
\hline \multirow{2}{*}{\multicolumn{2}{|c|}{ Model }} & \multicolumn{2}{|c|}{ Collinearity Statistics } \\
\hline & & Tolerance & VIF \\
\hline \multirow[t]{3}{*}{1} & CSRDI & 0.839 & 1.192 \\
\hline & ROA & 0.264 & 3.784 \\
\hline & ROE & 0.270 & 3.703 \\
\hline
\end{tabular}

To test the presence of heteroscedasticity in our linear regression model, we use Glejser test, which is computed by regressing absolute residuals from the original regression against the original regressors (plus intercept). To determine whether heteroscedasticity is present or not, it can be seen from the p-value of each independent variable that must be higher than 0.05 . From Table 4, we can conclude that all data is free from heteroscedasticity, which the p-values for CSR, ROA, and ROE are bigger than 0.05, i.e. $0.555,0.660$, and 0.410 , respectively. 
Table 4: Heteroscedastic Test

\begin{tabular}{|c|c|c|c|c|c|c|}
\hline \multirow{2}{*}{\multicolumn{2}{|c|}{ Model }} & \multicolumn{2}{|c|}{$\begin{array}{l}\text { Unstandardized } \\
\text { Coefficients }\end{array}$} & \multirow{2}{*}{$\begin{array}{c}\text { Standardized } \\
\text { Coefficients } \\
\text { Beta } \\
\end{array}$} & \multirow[t]{2}{*}{$\mathrm{T}$} & \multirow[t]{2}{*}{ Sig. } \\
\hline & & $\mathrm{B}$ & Std. Error & & & \\
\hline \multirow[t]{4}{*}{1} & (Constant) & 4.214 & 0.867 & & 4.858 & 0.000 \\
\hline & CSRDI & -0.014 & 0.023 & -0.102 & -0.596 & 0.555 \\
\hline & ROA & 0.024 & 0.054 & 0.135 & 0.443 & 0.660 \\
\hline & ROE & -0.035 & 0.041 & -0.251 & -0.833 & 0.410 \\
\hline \multicolumn{4}{|c|}{ a. Dependent Variable: Absolute Residual } & & & \\
\hline
\end{tabular}

To test the effects of environmental disclosures and environmental performance on financial performance, we employ a multivariate regression model as follows:

$$
\mathrm{PER}=\alpha_{0}+\alpha_{1} \mathrm{CSRDI}+\alpha_{2} \mathrm{ROA}+\alpha_{3} \mathrm{ROE}+\varepsilon_{1}
$$

Table 5: Regression Result

\begin{tabular}{|c|c|c|c|c|c|c|}
\hline \multirow{2}{*}{\multicolumn{2}{|c|}{ Model }} & \multicolumn{2}{|c|}{$\begin{array}{c}\text { Unstandardized } \\
\text { Coefficients } \\
\end{array}$} & \multirow{2}{*}{$\begin{array}{c}\text { Standardized } \\
\text { Coefficients }\end{array}$} & \multirow[t]{2}{*}{$\mathrm{t}$} & \multirow[t]{2}{*}{ Sig. } \\
\hline & & $\mathrm{B}$ & Std. Error & & & \\
\hline \multirow[t]{4}{*}{1} & (Constant) & -3.396 & 1.659 & & -2.047 & 0.047 \\
\hline & CSRDI & 0.369 & 0.045 & 0.769 & 8.225 & 0.000 \\
\hline & ROA & 0.048 & 0.103 & 0.078 & 0.466 & 0.644 \\
\hline & ROE & 0.042 & 0.079 & 0.088 & 0.531 & 0.598 \\
\hline
\end{tabular}

To test the effects of corporate social responsibility and profitability (ROA and ROE) simultaneously on firm value, we use
ANOVA to find F-value of the model as described in Table 6.

Table 6: ANOVA

\begin{tabular}{|l|l|c|c|c|c|c|}
\hline \multicolumn{2}{|c|}{ Model } & $\begin{array}{c}\text { Sum of } \\
\text { Squares }\end{array}$ & Df & Mean Square & F & Sig. \\
\hline \multirow{2}{*}{1} & Regression & 1623.650 & 3 & 541.217 & 32.338 & 0.000 \\
\cline { 2 - 7 } & Residual & 650.506 & 39 & 16.680 & & \\
\cline { 2 - 7 } & Total & 2274.155 & 42 & & & \\
\hline & R square & 0.71 & & & & \\
\hline & Adjusted R Square & 0.69 & & & & \\
\hline & $\begin{array}{l}\text { Std. Error of the } \\
\text { Estimate }\end{array}$ & 4.08 & & & & \\
\hline & & & & & \\
\hline
\end{tabular}

In this study, the results of first hypothesis testing support the association of corporate social responsibility disclosure and firm value $(\beta=0.369 ; p<0.01)$. It influences the firm value positively and significantly. This research is consistent with prior empirical findings stating the association of CSR activities and financial performance. This 
result could describe the behavior of Indonesian firms in reporting or disclosing its corporate social responsibilities' activities. It reflects their perspective and perception on social responsibility disclosure, which it is compulsory in nature to obey the Indonesian Law of Limited Liability Companies No. 40/2007; hence, most of them are involved in socially responsible activities. The Indonesian investors respond positively to this behavior and consequently. They appreciate more the companies' share market price. Therefore, these firms' value is influenced its corporate social responsibility report.

For the second hypothesis testing, the result reveals that profitability measures to do not affect the firm value significantly, i.e. ROA ( $\beta$ $=0.048, \mathrm{p}<0.01)$ and $\operatorname{ROE}(\beta=0.042, \mathrm{p}$ $<0.01$ ). In other words, this study does not support the hypothesis that profitability affects the firm value. Firm with good profitability will not always have a better firm value due to companies' financial performance is not always the determinant of firm value. It implicitly informs us that Indonesian investors do not always put financial performance indicators to value a firm. Finally, the result shows that CSR and profitability simultaneously affect financial performance ( $\mathrm{F}$-value $=32.338, \mathrm{p}<0.01$ ), as indicated in its $\mathrm{F}$ value that is significant at $\mathrm{p}$ $<0.01$ level. It indicates that those independent variables have a predictive capability to the dependent variable. In other words, CSR disclosure and profitability simultaneously could predict the firm's financial performance. A firm having CSR disclosure and financial performance could expect a certain level of firm value due to the good perception of market on company performance and ability to manage its social responsibility aspects well.

\section{Discussions}

In brief, our results are as follows. We find a positive association between corporate social responsibility and firm value. In other words, superior corporate social responsibility performers will get better firm value. This finding is consistent with some previous literature that evidence a positive and significant relation between CSR and firm value (Waddock and Graves, 1997; Roman, Hayibor, and Agle, 1999; Ruf, Muralidhar, Brown, Janney, Paul, 2001; Simpson and Kohers, 2002; Orlitzky et al., 2003; Tsoutsoura, 2004;). We also find that CSR disclosure and profitability measures simultaneously affect the firm value. This finding is in line with prior empirical findings that found a positive association between CSR disclosure, profitability, and firm value (Preston and O'Bannon, 1997; McWilliams and Siegel, 2001; Luce, Barber, and Hillman, 2001).

The results of this research are very important for a managerial perspective to create CSR strategies. Nowadays, stakeholder pressure highlights the need to include policies oriented towards social responsibility in companies' strategic management. This study shows that improving its positive CSR strategies are more likely to be perceived as a value creating for higher visibility firms, maintaining the efficiency of the firm, consolidate its financial situation, and answer the demands of its stakeholders. This issue could be of interesting managers since ignoring social and environmental factors when establishing the firm's strategic management policies could lead to a loss of competitiveness in the mid-long-term (Porter and Kramer, 2006). As the stakeholders' pressure on CSR disclosure is increasing, it can be argued that companies, which face a high degree of competitiveness, are more sensitive to social pressure and consequently, could provide more CSR disclosure and better CSR strategies.

The conclusions are also useful for agents operating in the market because they can introduce the social and environmental variables into the evaluation criteria for making investment decisions. At the same time, it is as well important to impose social responsibility disclosure as a compulsory 
report that companies should provide in its annual report. It will put the corporate social responsibility and environmental report as awareness media to both related-agents, i.e. the company and the stakeholders, to learn and understand more about the environment as inseparable part in daily business life. These empirical findings have implications for better understanding how a market value is being created as heterogeneous firms implement socially responsible strategies in their respective industries. In essence, we could further this study by investigating if and how CSR strategies, i.e. the effective management of a firm's stakeholders, whether it could potentially lead to value creation in public equity markets or not in other Southeast Asian countries' context.

\section{Conclusion}

The study has supported previous empirical findings in a certain degree. The positive and significant effect of CSR on firm value has lent a good indication for further research to explore this phenomenon in the context of Southeast Asian countries. Meanwhile, the positive and insignificant effect of profitability measures on firm value has provided supporting findings of financial performance effect generalization, which it opens the good opportunities to explore more widely in the context of comparative studies in Southeast Asian countries. Finally, the simultaneously effect of CSR and profitability on firm value provides basic findings of those variables that have not been proposed previously in many empirical studies in the context of developing countries' environment.

\section{References}

Al-Tuwaijri, S. A., Christensen, T. E. \& Hughes, K. E. (2004). "The Relations among Environmental Disclosure, Environmental Performance, and Economic Performance: A Simultaneous Equations Approach," Accounting, Organizations and Society, 29(56), 447-471.
Aupperle, K. E., Carroll, A. B. \& Hatfield, J. D. (1985). "An Empirical Examination of the Relationship between Corporate Social Responsibility and Profitability," Academy of Management Journal 28 (2), 446-463.

Berman, S. L., Wicks, A. C., Kotha, S. \& Jones, T. M. (1999). "Does Stakeholder Orientation Matter? The Relationship between Stakeholder Management Models and Firm Financial Performance," Academy of Management Journal 42 (5), 488-506.

Boutin-Dufrense, F. \& Savaria, P. (2004). "Corporate Social Responsibility and Financial Risk," The Journal of Investing 13, 57-66.

Brown, B. (1998). "Do Stock Market Investors Reward Companies with Reputations for Social Performance?," Corporate Reputation Review 1(3), 271-80.

Christopher, T., Hutomo, Y. B. S. \& Monroe, G. (1997). 'Voluntary Environmental Disclosure by Australian Listed Mineral Mining Companies: An Application of Stakeholder Theory,' The International Journal of Accounting and Business Society 5 (1), 42-65.

Clinebell, S. K. \& Clinebell, J. M. (1994). "The Effect of Advance Notice of Plant Closing on Firm Value," Journal of Management 20, 553564.

Cochran, P. L. \& Wood, R. A. (1984). "Corporate Social Responsibility and Financial Performance," Academy of Management Journal 27, 42-56.

Davidson, W. N. \& Worrell, D. L. (1988). "The Impact of Announcements of Corporate Illegalities on Shareholder Returns," Academy of Management Journal 31(1), 195-200.

Friedman, A. L. \& Miles, S. (2001). "SMEs and the Environment: Two Case Studies," Eco Management and Auditing 8(4), 200-9. 
Frooman, J. (1997). "Socially Irresponsible and Illegal Behavior and Shareholder Wealth," Business \& Society 36(3), 221-50.

Gelb, D. S. \& Strawser, J. A. (2001). "Corporate Social Responsibility and Financial Disclosures: An Alternative Explanation for Increased Disclosure," Journal Business Ethics $33,1-13$.

Gray, R., Javad, M., Power, D. M. \& Sinclair, C. D. (2001). "Social and Environmental Disclosure and Corporate Characteristics: A Research Note and Extension," Journal of Business Finance \& Accounting 28(3/4), 327356.

Guthrie, J. \& Parker, L. D. (1990). 'Corporate Social Disclosure Practice: A Comparative International Analysis,' Advance in Public Interest Accounting 3, 159-75.

Hackston, D. \& Milne, D. M. (1996). "Some Determinant of Social and Environmental Disclosures in the New Zealand Companies," Accounting, Auditing and Accountability Journal 9 (1), 77-108.

Hannon, J. M. \& Milkovich, G. T. (1996). "The Effect of Human Resource Reputation Signals on Share Prices: An Event Study," Human Resource Management 35 (3), 405-424.

Haron, H., Yahya, S., Chambers, A., Manasseh, S. \& Ismail, I. (2004). "Level of Corporate Social Disclosure in Malaysia," Fourth Asia Pacific Interdisciplinary Research in Accounting Conference, 4-6 July, Singapore.

Hughes, S. B., Anderson, A. \& Golden, S. (2001). "Corporate Environmental Disclosures: Are They Useful in Determining Environmental Performance?," Journal of Accounting and Public Policy, 20, 217-240.

Jones, P., Comfort, D. \& Hiller, D. (2007). "Marketing and Corporate Social Responsibility within Food Stores," British Food Journal Vol.109 No.8, 582-593.
Lorca, P. \& Garcia-Diez, J. (2004). "The Relation between Firm Survival and the Achievement of Balance among Its Stakeholders," International Journal of Management 22(1), 93-9.

Luce, R. A., Barber, A. E. \& Hillman, A. J. (2001). "Good Deeds and Misdeeds: A Mediated Model of the Effect of Corporate Social Performance on Organizational Attractiveness," Business and Society 40 (4), 397.

Mahoney, L. \& Roberts, R. W. (2007). "Corporate Social Performance, Financial Performance, and Institutional Ownership in Canadian Firms," Accounting Forum 31, 233253.

Mallin, C. A., Saadouni, B. \& Briston, R. J. (1995). "The Financial Performance of Ethical Investment Funds," Journal of Business Finance \& Accounting 22(4), 483-97.

Margolis, J. D. \& Walsh, J. P. (2003). "Misery Loves Companies: Rethinking Social Initiatives by Business," Administrative Science Quarterly, Vol. 48, 268-305.

McGuire, J. B., Sundgren, A. \& Schneeweis, T. (1988). "Corporate Social Responsibility and Firm Financial Performance," Academy of Management Journal 31 (4), 854-872.

McWilliams, A. \& Siegel, D. (1997). "Event Studies in Management Research: Theoretical and Empirical Issues," Academy of Management Journal 40 (3), 626-657.

McWilliams, A. \& Siegel, D. (2001). "Corporate Social Responsibility: A Theory of the Firm Perspective," Academy of Management Review 26 (1), 117-127.

Moore, G. \& Robson, A. (2002). "The UK Supermarket Industry: An Analysis of Social and Financial Performance," Business Ethics a European Review 11(1), 25-39.

Nurlela \& Islahudin. (2008). 'Pengaruh Corporate Social Responsibility Terhadap Nilai Perusahaan Dengan Prosentase 
Kepemilikan Manajemen Sebagai Variabel Moderating,' (The Effect of Corporate Social Responsibility on Firm Value with Managerial Ownership As Moderating Variable). Prosiding Simposium Nasional Akuntansi XI (Proceeding 11th National Accounting Symposium). Makassar.

Orlitzky, M., Schmidt, F. L. \& Rynes, S. L. (2003). "Corporate Social and Financial Performance: A Meta-Analysis," Organization Studies 24 (3), 403-441.

Pava, M. L. \& Krausz, J. (1996). "The Association between Corporate SocialResponsibility and Financial Performance The Paradox of Social Cost," Journal of Business Ethics 15 (3), 321-357.

Posnikoff, J. F. (1997). "Disinvestment from South Africa: They Did Well by Doing Good," Contemporary Economic Policy 15 (1), 76-86.

Post J. E., Preston, L. E. \& Sauter-Sachs, S. (2002). Redefining the Corporation: Stakeholder Management and Organizational Wealth. Stanford University Press: California.

Preston L. E. \& O’Bannon, D. P. (1997). "The Corporate Social - Financial Performance Relationship: A Typology and Analysis," Business and Society 36 (4), 419.

Rakhiemah, A. N. \& Agustia, D. (2009). Pengaruh Kinerja Lingkungan Terhadap Corporate Social Responsibility (CSR) Disclosure Dan Kinerja Finansial Perusahaan Manufaktur Yang Terdaftar Di Bursa Efek Indonesia (The Effect of Environmental Performance on Corporate Social Responsibility Disclosure and Financial Performance of Indonesian Manufacturing Firms). Prosiding Simposium Nasional Akuntansi XII (Proceeding 12th National Accounting Symposium). Palembang.

Roberts, P. W. \& Dowling, G. R. (2002). "Corporate Reputation and Sustained Superior Financial Performance," Strategic Management Review 23, 1077-93.
Roman, R. M., Hayibor, S. \& Agle, B. R. (1999). "The Relationship between Social and Financial Performance: Repainting a Portrait," Business and Society 38, 109-18.

Rosen, B. N., Sandler, D. M. \& Shani, D. (1991). "Social Issues and Socially Responsible Investment Behavior: A Preliminary Empirical Investigation," Journal of Consumer Affairs 25 (2), 221-34.

Ruf, B. M., Muralidhar, K., Brown, R. M., Janney, J. J. \& Paul, K. (2001). "An Empirical Investigation of the Relationship between Change in Corporate Social Performance and Financial Performance: A Stakeholder Theory Perspective," Journal of Business Ethics 32, 143-156.

Simpson, W. G. \& Kohers, T. (2002). "The Link between Corporate Social and Financial Performance: Evidence from the Banking Industry," Journal of Business Ethics 35, 97109.

Stanwick, P. A. \& Stanwick, S. D. (1998). "The Relationship between Corporate Social Performance and Size, Financial and Environmental Performance," Journal of Business Ethics, 17(2): 195-204.

Subroto, P. H. (2003). 'A Correlational Study of Corporate Social Responsibility and Financial Performance: An Empirical Survey toward Ethical Business Practices in Indonesia. Unpublished Doctoral Dissertation,' Capella University.

Teoh, S. H., Welch, I. \& Wazzan, C. P. (1999). "The Effect of Socially Activist Investment Policies on the Financial Markets: Evidence from the South African Boycott," Journal of Business 72 (1), 35-89.

The Law of the Republic of Indonesia No. 40 2007 on Limited Liability Companies, Chapter $1-60$.

Thompson, P. \& Zakaria, Z. (2004). "Corporate Social Responsibility Reporting in Malaysia Progress and Prospects," Journal of Corporate Citizenship 13, 125-136. 
Thorne, D., Ferrell, O. \& Ferrell C. (1993). 'Business and Society: A Strategic Approach to Corporate Citizenship,' Houghton Mifflin Co.: Boston.

Tsang, E. W. K. (1998). "A Longitudinal Study of Corporate Social Reporting in Singapore: The Case of the Banking, Food and Beverage, and Hotel Industries," Accounting Auditing and Accountability Journal, 11(5), 624-635.

Tsoutsoura, M. (2004). "Corporate Social Responsibility and Financial Performance," Working Paper Series (7), Center for Responsible Business, Berkeley: University of California.

Uchida, S. \& Ahmed, S. U. (2009). "Corporate Social Responsibility and Financial Performance Linkage: A Preliminary Study for the Conceptual Framework," NAOSITE 50, 43-51.

Waddock, S. A. \& Graves, S. B. (1997). "The Corporate Social Performance-Financial Performance Link," Strategic Management Journal 18, 303-19.

Weber, M. (2008). "The Business Case for Corporate Social Responsibility: A CompanyLevel Measurement Approach for CSR," European Management Journal 26, 247-61.

Wiseman, P. (1982). "An Evaluation of Environmental Disclosures Made In Corporate Annual Reports," Accounting, Organizations and Society, Vol.7 No.1, 53-63.

Worrell, D. L., Davidson, W. \& Sharma, V. M. (1991). "Layoff Announcements and Stockholder Wealth," Academy of Management Journal, 34 (3), 662-678.

Wright, P. \& Ferris, S. P. (1997). "Agency Conflict and Corporate Strategy: The Effect of Divestment on Corporate Value," Strategic Management Journal 18 (1), 77-83.

Wu, M. L. (2006). "Corporate Social Performance, Corporate Financial Performance and Firm Size: A Meta-
Analysis," Journal of American Academy of Business, Vol. 8, 163-71.

Yoshikawa, T. \& Phan, P. H. (2003). "The Performance Implications of OwnershipDriven Governance Reform," European Management Journal, 21 (6), 698-06. 